\title{
'Platformisation' of work: An EU perspective on Introducing a legal presumption
}

European Labour Law Journal 2022, Vol. I3(I) 66-80 (C) The Author(s) 2021 (c) (i)

Article reuse guidelines: sagepub.com/journals-permissions DOI: $10.1177 / 20319525211063112$ journals.sagepub.com/home/ell

@SAGE

\section{Miriam Kullmann*}

\begin{abstract}
For some time now, the European Commission has stressed the need to address the ongoing misclassification of employment status in platform work and has thus considered introducing a rebuttable presumption of employment status or a reversal of the burden of proof. This contribution focuses on the benefits and limitations of introducing a rebuttable legal presumption in EU labour law as an evidentiary means to improve the working conditions of platform workers. In doing so, some general remarks on rebuttable legal presumptions will be made, while also offering some comparative legal insights, before exploring their potential benefits and limitations in the context of EU labour law in general and platform work in particular. This contribution will finish with an analysis of how such a presumption could be integrated in the current EU social acquis.
\end{abstract}

\section{Keywords}

Platform workers, classification, rebuttable legal presumption, EU social partner consultation

\section{Introduction}

Characteristic of platform work is its business model which heavily relies on the fragmentation of work largely to prevent or avoid labour-related costs, resulting in piecemeal work or micro tasks resulting in smaller amounts of pay per task. This is, on the one hand, done through (often

\footnotetext{
Corresponding author:

* Dr. Miriam Kullmann, Assistant Professor in Labour Law, VU Amsterdam, visiting scholar Harvard University Weatherhead Center for International Affairs, and Member of the European Committee of Social Rights. I wish to thank Conrad Greiner for his excellent research assistance.

Email: m.kullmann@vu.nl
} 
falsely, as some national court rulings have shown $)^{1}$ classifying platform workers as selfemployed persons, so that they will be barred from (most) labour protections, for they usually do not apply to working relationships that are not institutionalised by an employment contract. On the other hand, by breaking down work into small bits and pieces with remuneration adjusted to that, the question is whether platform workers can, in any way, secure a living. Nowadays, platform work has evolved so as to include a plethora of activities, most prominently in areas such as transportation, food delivery and domestic care and household services, all of them, though to a varying degree, subordinated to the fundamental idea of flexibility that is managed by algorithmic decision-making. ${ }^{2}$

These developments ultimately raise the question of how we value work and what the role for labour law is in counteracting the tendency that platform workers are prevented from benefiting from at least some protections offered by labour regulations. It is apposite to ask these questions, for if labour law is understood to consist of rules that are protective of workers' interests, while an increasing number of workers are excluded from its personal scope and thus cannot benefit from this body of law, what, then, is the role of labour law? This resonates with what Michael Sandel wrote in his seminal book What Money Can't Buy: The Moral Limits of Markets: '[s]ometimes, market values crowd out nonmarket values worth caring about. ${ }^{3}$ Therefore, in order to (re)value (platform) work, we need to take bold steps and we need them now. It is against this background that one of the questions that has arisen is whether the adoption of a (rebuttable) legal presumption on the existence of an employment relationship or contract would be such a step. Interestingly, such a rebuttable legal presumption - inter alia, to address misclassification of platform workers - has already been introduced in the US through the AB5 initiative. A number of EU Member States have rebuttable legal presumptions, mostly adopted with a view to tackling misclassification in the context of atypical work relationships. Hence, it can be questioned whether the rebuttable legal presumption serves as a template for the introduction of an EU-wide applicable presumption which the European Commission is currently preparing. In its consultation document, the European Commission particularly stresses the need to address the ongoing misclassification of employment status in platform work and thus considers introducing a rebuttable presumption of employment status or a reversal of the burden of proof. ${ }^{4}$

This contribution, therefore, focuses on the benefits and limitations of introducing a rebuttable legal presumption in EU labour law as an evidentiary means to improve the working conditions of platform workers. In doing so, I will first offer some remarks on rebuttable legal presumptions in general, while also offering some comparative legal insights (section 2), before exploring their potential benefits and limitations in the context of EU labour law in general and platform work in particular (section 3). This is followed by an analysis of how such a presumption could be integrated in the current EU social acquis (section 4).

1. To mention an example from The Netherlands: Appeals Court Amsterdam Deliveroo Netherlands BV/FNV ECLI:NL: GHAMS:2021:392. See also Christina Hiessl, 'The Classification of Platform Workers in Case Law: A Cross-European Comparative Analysis' (2021) Comparative Labor Law \& Policy Journal (forthcoming).

2. See the contribution by Jeremias Adams-Prassl in this issue.

3. Michael Sandel, What Money Can't Buy: The Moral Limits of Markets (London, Penguin Books, 2013) 9.

4. Commission, 'First phase consultation of social partners under Article 154 TFEU on possible action addressing the challenges related to working conditions in platform work' (Consultation Document) C(2021) 1127 final, 27. 


\section{A rebuttable legal presumption to protect platform workers}

One of the essential challenges, from a labour law perspective, in relation to platform work, is the legal status of platform workers. Its importance becomes clear as ' $[t]$ he labour status of people working in the online platform economy is key to their socio-economic protection'. Still, having an employment contract or relationship or being classified as an employee is the key to accessing labour law protection, although some Member States use in-between worker categories, so-called employee-like persons, offering partial protection by labour law and social security law. ${ }^{6}$ While the latter offers some protection for workers, I believe that adding a third, in-between, category within the EU social acquis would be counterproductive. On the one hand, an in-between or third worker category would most likely not reduce complexity, but would, to some extent, improve legal certainty for platform workers and online platforms. Further, on the other hand, such a category would exclude, by law, platform workers from greater and better protection that is offered by labour law, including non-discrimination law. Hence, the road to a higher level of protection for platform workers would be foreclosed. Finally, it seems to be unclear whether introducing another category of workers would actually contribute to establishing greater clarity as to the classification of platform workers and, therefore, whether it would be less likely to result in litigation. ${ }^{7}$ The legal classification of relationships is, and will continue to be, a central part of labour law, unless it is decided that all economically active persons will be protected by a universal labour law for which no legal classification, except for an economic activity, will be needed. This is not to say that codifying a legal presumption aimed at protecting platform workers will be the panacea that will solve the classification question in relation to platform work. Nevertheless, introducing and, above all, actually invoking, a rebuttable legal presumption might have important benefits - especially if we understand labour law as being protective of workers' interests - for platform workers and those enforcing compliance with labour rights, for it shifts the burden of proving the opposite towards the employing entity.

Through a comparative labour law lens, we find that the majority of the EU Member States - that is, 17 - do not or no longer have a legal presumption regarding the employment relationship. ${ }^{8}$ The remaining 10 EU Member States that have a legal presumption do regulate general presumptions that are widely applicable to all kinds of working relationships (Croatia, Estonia, Greece, Malta, the Netherlands, Portugal, Slovenia, Spain) or presumptions that apply to particular groups of workers or sectors (Belgium, France). ${ }^{9}$ None of the presumptions have been adopted with the aim of addressing the misclassification in the platform economy, mostly because at the time when these presumptions were adopted, platform work was not en vogue yet. However, following

5. Sacha Garben, “'Old” Rules and Protections for the "New” World of Work' (Social Europe, <https://socialeurope.eu/oldrules-and-protections-for-the-new-world-of-work> accessed 19 July 2021.

6. See Antonio Aloisi, Section 2, in this issue.

7. Valerio De Stefano, “I Now Pronounce You Contractor": Prop22, Labour Platforms and Legislative Doublespeak' (13 November 2020) UK Labour Law <https://uklabourlawblog.com/2020/11/13/i-now-pronounce-you-contractorprop22-labour-platforms-and-legislative-doublespeak-by-valerio-de-stefano/> accessed 19 July 2021.

8. These are: Austria, Bulgaria, Cyprus, Czech Republic, Denmark, Finland, Germany, Hungary, Ireland, Italy, Latvia, Lithuania, Poland, Romania, Slovakia, Sweden.

9. A brief overview on the issue of legal presumptions can be found in: Bernd Waas and Guus Heerma van Voss (eds), Restatement of Labour Law in Europe: The Concept of Employee, vol vol I (Oxford, Hart, 2017). See for another overview: ILO, Regulating the Employment Relationship in Europe: A Guide to Recommendation No. 198 (European Labour Law Network, 2013) 28-30. 
the European Commission's first-phase consultation document, the Netherlands and Spain are considering the introduction of a legal presumption for platform work, ${ }^{10}$ although this raises the question of the extent to which the general legal presumption would be sufficient to tackle classification questions in this context. In the meantime, Spain adopted a legal presumption for platform work in May 2021. ${ }^{11}$ Nevertheless, a common reason why legal presumptions have been integrated into systems of labour law is to fight the (deliberate) misclassification of workers as self-employed persons in general. It is therefore not difficult to see why a rebuttable legal presumption might be adopted at the EU level to ensure the correct classification of platform workers and, as a result, to entitle them to the applicable EU and national labour rights. ${ }^{12}$

One legal presumption that has been established, inter alia, with the aim of addressing misclassification in online and offline economies, ${ }^{13}$ and which therefore particularly addresses platform workers, is the AB5 presumption, which came into force on 1 January 2020 in California. It presumes that platform workers are employees, unless the employer (i.e., the online platform) can demonstrate that the three parts of the so-called $\mathrm{ABC}$ test do not apply to the working relationship. ${ }^{14}$ For this presumption to be rebutted, according to the test, online platforms must prove that workers: (a) are free from control and direction by the hiring company; (b) perform work outside the usual course of business of the hiring entity; and (c) are independently established in that trade, occupation, or business.

The AB5 presumption contains two key elements: first, it establishes that platform workers are classified as employees until the opposite has been demonstrated and, second, it provides criteria through which the platform can demonstrate that the platform worker is actually not an employee. Despite its positive acclaim, with one of the most expensive campaigns in US history, platform companies Uber, Lyft, Postmates (owned by Uber), DoorDash and Instacart invested USD203 million in a ballot initiative campaign, Proposition 22, to explicitly exempt so-called Transportation Network Companies and Delivery Network Companies from AB5. Most importantly, Proposition 22 determines that platform workers are independent contractors, offering these workers a more limited set of protections in return. ${ }^{15}$ Also at the EU level, as the reactions of the European Commission's first-phase consultation phase has shown, employer organisations seem to be hesitant about introducing a legal presumption by emphasising that the determination of whether a platform worker is an employee should be done on a case-by-case basis at national level so as to respect the different Member State models. ${ }^{16}$

\section{The benefits and limitations of introducing a rebuttable legal presumption in EU law}

A legal presumption in favour of the employment relationship can be seen as an evidentiary instrument following which work relations that meet all relevant criteria will be classified as employment relationships. Yet, where the contractual relationship between the platform and the platform worker

10. C(2021) 1127 final, 8 .

11. Royal Decree-law 9/2021 of 11 May 2021. See for a review of the new Rider Law in Spain Antonio Aloisi's contribution.

12. C(2021) 1127 final, 27.

13. See on this, more extensively, the contribution by Veena Dubal in this issue.

14. AB5 codifies Dynamex v. Superior Court of Los Angeles California Supreme Court, 4 Cal. 5 th 903 (2018).

15. See on this, more extensively, the contribution by Veena Dubal in this issue.

16. Commission, 'Second-phase consultation of social partners under Article 154 TFEU on possible action addressing the challenges related to working conditions in platform work' (Consultation Document) C(2021) 4230 final, 3. 
is deemed to be an employment relationship, employing entities could counter that presumption by establishing facts, mostly in a legal procedure before a national court, to prove that the platform worker actually is self-employed. Thus, the legal presumption will shift the burden of proving that there is no employment relationship onto the online platform. Before discussing the possible effects of introducing a rebuttable legal presumption in EU law (see section 4, below), I will explore the benefits and limitations of such a presumption. When considering a new provision that aims to protect workers, and in this case platform workers, the crucial question is whether that provision is actually able to protect workers against misclassification or not. Because if it would not assist individual or a group of platform workers, particularly where collective lawsuits are possible, then the relevance of introducing a new legal instrument will be questionable and it might be better to refrain from adopting a 'dead letter' provision and find an alternative way of protecting platform workers.

\section{I The potential benefits: legal certainty, collective representation and bargaining, and monitoring and enforcement}

Introducing a rebuttable legal presumption within EU law may have three benefits. First, it might offer legal certainty among the different stakeholders that are involved in the labour market, most importantly, but not only, platform workers and online platforms. ${ }^{17}$ Legal certainty is a general principle in law and should therefore be taken seriously in the world of work, also for reasons of monitoring and enforcement, which will be addressed later (third benefit, below). Creating a rebuttable legal presumption counteracts the insecurity that exists around the legal classification of a working relationship, as, by law, contracts between platforms and their workers will be classified as employment relationships, unless the opposite can be proven by the employing entity. Although, in general, there is a possibility to ask the national court to reclassify a work relationship, the automatic classification in favour of the employment relationship by a legal presumption quite importantly shifts the burden of proving that the working relationship is not based on an employment contract onto the online platform. This can be justified on the ground that it is the platform itself that stipulates that it contracts with self-employed workers and hence avoids any (financial) obligations that may arise under applicable labour law, as well as social security and pension laws.

Second, and in line with the previously mentioned advantage, a legal presumption may also have important benefits for social partners, and trade unions, in particular. Through clarifying the legal relationship between platform workers and online platforms, trade unions can more easily focus on representing, and thus addressing, platform workers in collective agreements, for they will be covered by the personal scope of such agreements. That means that by considering the work relationships of platform workers to be relationships of employment - unless the opposite can be demonstrated by the employing entity - there will be no discussion of whether competition law restricts collective bargaining or vice versa, because platform workers will not, in the first place, be considered as entrepreneurs. ${ }^{18}$ Adopting a legal presumption with the effect that platform

17. Another stakeholder would be the state, in particular, with regard to social security contributions and income taxation.

18. Case C-413/13 FNV Kiem ECLI:EU:C:2014:2411. See, for relevant scholarly contributions on this issue: Ioannis Lianos, Nicola Countouris and Valerio De Stefano, 'Re-thinking the Competition Law/Labour Law Interaction: Promoting a Fairer Labour Market' (2019) 10 European Labour Law Journal 291. See also the European Commission consultation on Collective Bargaining Agreements for Self-Employed - Scope of Application of EU Competition Law Rules (Inception Impact Assessment Ares(2021)102652). 
workers will be considered to have an employment relationship will result in excluding these workers from the scope of competition law. As Ioannis Lianos, Nicola Countouris and Valerio De Stefano rightly note, 'certain types of activity are more conducive to be considered as leading to a false self-employed status'. Applying this reasoning to platform work and following what they refer to as a 'categorisation approach', specific criteria could be established that, 'if satisfied, would establish a rebuttable presumption that the collective agreement was concluded by false self-employed'. ${ }^{19}$ The suggested approach would, from a competition law perspective, put a halt to an under-inclusive applicability of collective agreements and would be a complementary instrument to a legal presumption. Yet it is questionable whether part of the problem is the absence of any protection for the self-employed/entrepreneur, particularly because the binary divide in labour law is an all-or-nothing approach.

Falling within the scope of a collective agreement, if one or more agreements apply in the sectors or branches where platform workers are providing their services or where particular collective agreements have been agreed upon for platform workers, would allow these workers to at least benefit from a certain set of rights, including sectoral minimum wages and working time provisions, both offering an element of security and stability in terms of income and working time. Through the adoption of a legal presumption, then, the democratic element in working relationships, as, inter alia, acknowledged in Art 28 EUCFR, will be improved by strengthening collective representation and bargaining for platform workers. It will, furthermore, provide a counterbalance to the ever-present bargaining imbalance between workers and employers, and hence contribute to the idea of labour law being protective of workers' interests.

A third advantage, as indicated earlier, is that a legal presumption can improve the monitoring and enforcement of compliance with labour law as the law stipulates that platform workers have an employment relationship. As I have explored in the context of cross-border worker mobility, monitoring and enforcement is an often-neglected, yet very important, area. ${ }^{20}$ This is, as Niklas Selberg has noted, 'surprising and disappointing', '[g]iven labour law's practical orientation toward making a difference for workers' ${ }^{21}$ Clearly, monitoring and enforcement is practical, but requires a practical infrastructure to be effective in its procedures and outcomes. Where material rights are granted by law but not complied with, proper and frequent monitoring and enforcement methods should be in place to ensure compliance with applicable regulations. With a few exceptions, such as Directive 2014/67/EC on the enforcement of Directive 96/71/EC on the transnational posting of workers, most EU law is limited to setting out the material rights involved in working relationships, thereby largely ignoring the consequences of rights being not (correctly) applied. Rights and remedies are two sides of the same coin, meaning that where there is a right, there must also be a

19. Lianos, Countouris and De Stefano, 'Re-thinking the Competition Law/Labour Law Interaction' 316.

20. Miriam Kullmann, Enforcement of Labour Law in Cross-Border Situations: A Legal Study of the EU's Influence on the Dutch, German, and Swedish Enforcement Systems (Deventer, Kluwer, 2015). See on enforcement of labour law: Jonas Malmberg, Barry Fitzpatrick, Michael Gotthardt, Sylvie Laulom, Antonio Lo Faro, Taco van Peijpe and Andrzej Swiatkowski, Effective Enforcement of EC Labour Law (Kluwer Law International, 2003) and, most recently, Louise Munkholm, Re-Inventing Labour Law Enforcement: A Socio-Legal Analysis (Oxford, Hart, 2020).

21. Niklas Selberg, 'Reflections on the Enforcement of Labour Law: A Review of Re-inventing Labour Law Enforcement. A Socio-Legal Analysis by Louise Munkholm Hart, 2020' (2021) 37 International Journal of Comparative Labour Law and Industrial Relations 313. 
remedy. ${ }^{22}$ But there must also be actual monitoring and enforcement to ensure that rights are taken seriously. Principally, by virtue of the principle of national procedural autonomy, ${ }^{23}$ Member States are free to arrange their monitoring and enforcement system as they think best in absence of EU harmonising measures. To ensure - at least, to a certain extent - that EU law is uniformly applied, Member States' monitoring and enforcement mechanisms must respect the principles of equivalence and effectiveness. $^{24}$

Within labour law, generally in all EU Member States, three enforcement methods can be distinguished, albeit they may be used in different ways and combinations. First, the judicial enforcement method is a traditional method used to seek compliance with the law, which leaves national judges a great deal of room for the interpretation and application of labour law in cases initiated by individual employees or their representatives. The effectiveness of this method, however, is questionable, as for many workers, suing their employer is a step too far, often resulting in job loss. Second, within the industrial relations enforcement method, supervision and enforcement of (collective) labour law is entrusted to the trade unions (or the works councils), together with the employers and/or their representatives. The method's effectiveness largely depends on the efforts made by the social partners and the national legal system within which they operate. Hence, a proactive attitude and some institutionalisation of processes are required. Third, the administrative enforcement method leaves the supervision and enforcement of the rules to public authorities, including labour inspectorates or equality agencies. This method is cost-intensive for states, which has resulted in many authorities facing a reduction in staff and an increase in bureaucracy rather than being able to actually go to the places where work is performed or to check the algorithms used by online platforms to assess whether and to what extent online platforms comply with applicable laws and regulations. Ultimately, a legal presumption thus may actually and practically help bodies involved in the monitoring and enforcement to ensure compliance with labour law, for it would allow them to start from the assumption that a platform worker is in an employment relationship and, if not, that, as an ultimum remedium, appropriate sanctions might be imposed.

\subsection{The limitations: Not a panacea}

Despite the benefits of establishing a European-wide applicable legal presumption to improve the situation of platform workers which online platforms can rebut, it is not a panacea that will solve all classification problems in relation to platform work. Two limitations, however, are worth mentioning here.

22. This is expressed by the Latin phrase 'ubi ius, ibi remedium'. See, for a discussion of the relationship between rights and remedies: Walter van Gerven, 'Of Rights, Remedies and Procedures' (2000) 37 Common Market Law Review 501; Thomas Eilmansberger, 'The Relationship Between Rights and Remedies in EC Law: In Search of the Missing Link' (2004) 41 Common Market Law Review 1199.

23. See, on national procedural autonomy Mariolina Eliantonio, 'The Future of National Procedural Law in Europe: Harmonisation vs. Judge-made Standards in the Field of Administrative Justice' (2009) 13 Electronic Journal of Comparative Law 1; Matej Accetto and Stefan Zleptnig, 'The Principle of Effectiveness: Rethinking Its Role in Community Law' (2005) 11 European Public Law 357; Constantinos N Kakouris, 'Do the Member States Possess Judicial Procedural “Autonomy”?' (1997) 34 Common Market Law Review 1389.

24. Eliantonio, 'The Future of National Procedural Law in Europe' 1. Two seminal cases that must be mentioned here are: Case 33/76 Rewe (Saarland) ECLI:EU:C:1976:188 and Case 45/76 Comet ECLI:EU:C:1976:191 
The first one, provided by a 2017 EU-OSHA report, highlights that a legal presumption would not necessarily resolve the classification difficulties. While classification certainly is, and will remain, an issue to deal with, especially when it comes to the criteria used, the 'thin' argument put forward against introducing a legal presumption, namely, that it would still require a case-by-case approach (by courts), seems, in my opinion, not convincing enough to dismiss the idea altogether. ${ }^{25}$ One reason is that classification in general has, and always will, require a case-by-case assessment, with or without a legal presumption. However, and this would be the difference if a rebuttable legal presumption were to be introduced at EU level and if Member States could not deviate from it by offering an alternative instrument, by law, all platform workers would be considered to be working under an employment relationship until the opposite could be demonstrated. Because a rebuttable legal presumption shifts the burden of proving that the platform worker is self-employed onto the online platform, to a certain extent, a platform worker herself does not bring a case against the employing entity in the first place, asking a national (labour) court to assess the working relationship.

Another limitation of introducing a new legal instrument at the EU level might be, as Guy Davidov notes, that such an instrument 'can lead employers to change the method of work organization, thus opening new uncertainties. At the end of the day, if our goal is first and foremost to ensure protection to those who need it, rather than ensure determinacy, some judicial discretion is unavoidable. ${ }^{26}$ While I agree with Guy Davidov's statement that a new legal instrument may cause employing entities to find different or even new regulatory gaps to circumvent existing labour law obligations, I believe that a legal presumption could work well, provided, however, it is backed up by effective enforcement through all three enforcement methods mentioned earlier (section 3.1, above). And above all, where businesses do not want to comply with labour regulations, for instance, to minimise labour costs, they always find a way of doing so - hence actual enforcement becomes a crucial element in this. Still, even with a rebuttable legal presumption, courts retain their discretionary power to reclassify an employment relationship, if the employing entity successfully submits proof of the opposite, i.e. that the platform worker is actually selfemployed. Based on what has been said, it seems that none of the two arguments are, when compared with the advantages, compelling enough to frustrate the adoption of a rebuttable legal presumption in EU law.

\section{Introducing a rebuttable legal presumption for platform workers within the EU's legal framework}

\section{I Discussions on the importance of a rebuttable legal presumption for platform workers}

It has been argued that there are valid reasons to seriously consider introducing a rebuttable legal presumption that would apply to platform workers. In its 2006 Green Paper, the European Commission emphasised the need for proper monitoring and enforcement and, in this context,

25. EU-OSHA, Protecting Workers in the Online Platform Economy: An Overview of Regulatory and Policy Developments in the EU (2017) 4-5.

26. Guy Davidov, 'The Status of Uber Drivers: A Purposive Approach' (2017) 6 Spanish Labour Law and Employment Relations Journal 6, 9. 
referred to mandatory rebuttable legal presumptions within national legal systems as a means to combat disguised employment. ${ }^{27}$ Again, in 2021, the European Commission picked up the idea of establishing a legal presumption that is rebuttable while, at the same time, stressing that it 'could also aim at facilitating the enforcement of existing labour legislation and strengthening controls and inspections of digital labour platforms, to detect and pursue possible cases of misclassification. ${ }^{28}$ It is unclear from the Consultation Document, in both the first and second phases, whether enforcement is seen as an alternative to introducing a legal presumption, but it may turn out to be complementary as well. However, in the second phase Consultation Document, the European Commission acknowledges the advantage of a rebuttable legal presumption, being that it can provide 'a clear rule and strengthen the work of labour authorities or social security institutions to reclassify them as workers', which could be an indication of the fact that a presumption is an instrument improving the enforcement authorities' work. ${ }^{29}$ Such a presumption would clearly meet the aim mentioned in the second phase consultation, which is to facilitate employment status classification and ensure access to labour and social protection rights. ${ }^{30}$

The European Commission's suggestion of considering the adoption of a rebuttable legal presumption to improve the protection of platform workers is supported by labour law scholars. Martin Risak, for instance, seems to justify the adoption of a rebuttable legal presumption, as part of the solution and 'at the heart of a "Directive on Fair Working Conditions in the Platform Economy", by emphasising that "it is only the platform in its capacity as contractual partner of both the user and the platform worker which organises the service and where all the strings come together that will be in the position to actually provide evidence revealing the exact web of contracts as well as actual practice'. ${ }^{31}$ The 2018 Draft for an EU Directive on Platform work by Joachim Schuster and Leonie Nora Rinke supports this reasoning. ${ }^{32}$ Importantly, a legal presumption, albeit not yet known in all EU Member State jurisdictions, could 'recalibrate the massive imbalance of information and provide platform workers with the necessary means to actually enforce their rights'. ${ }^{33}$ Also, there are, as Valerio De Stefano rightly notes in reference to the 2006 ILO Employment Relationship Recommendation No 198, examples of online platforms that have correctly classified or even reclassified their workers as employees. ${ }^{34}$ Together with Nicola Countouris, Valerio De Stefano also considers the introduction of a legal presumption of employer status in respect of the entity or entities 'substantially determining' the terms of engagement and employment of the worker as a valid way of offering labour law protection to platform workers, to tackle the issue of having multiple employing entities. ${ }^{35}$ In its Recommendation No 198, the ILO determined, early on, that states should, inter alia, consider

27. Commission, 'Green Paper on Modernising labour law to meet the challenges of the 21 st century' (Communication) $\mathrm{COM}(2006) 708$ final, 11.

28. C(2021) 1127 final, 27.

29. C(2021) 4230 final, 21-22.

30. ibid 1-2.

31. E.g., Martin Risak, Fair Working Conditions for Platform Workers: Possible Regulatory Approaches at the EU Level (Friedrich-Ebert-Stiftung, 2017) 14.

32. J Schuster and LN Rinke, Draft EU Directive on Platform Work (June 2018) 3.

33. Risak, 'Fair Working Conditions for Platform Workers' 14.

34. Valerio De Stefano, 'The Rise of the "Just-In-Time Workforce": On-Demand Work, Crowdwork and Labour Protection in the "Gig-Economy" (2016) 37 Comparative Labor Law \& Policy Journal 471, 500.

35. Nicola Countouris and Valerio De Stefano, New Trade Union Strategies for New Forms of Employment (ETUC, 2019$) 17$. 
adopting a 'legal presumption that an employment relationship exists where one or more relevant indicators are present'. ${ }^{36}$

\subsection{The potential legal basis for an EU initiative on platform workers}

Even though the European Commission, likely following requests by some scholars as well as existing national examples, has suggested the possibility of introducing a rebuttable legal presumption, it has not yet engaged - at least, not explicitly - with the question of what the legal basis or bases for this could be. ${ }^{37}$ The most obvious provision on which a presumption could be based would be Art 153(2)(b) in conjunction with Art 153(1)(b) TFEU. ${ }^{38}$ In its first-phase Consultation Document, the European Commission emphasises that 'EU action can support Member States to ensure fair conditions and opportunities in platform work regarding employment, working conditions, and social protection', which could be interpreted as referring to Art 153 TFEU. ${ }^{39}$ Similarly, Art 153 TFEU also serves as the legal basis for Directive (EU) 2019/1152 on transparent and predictable working conditions in the European Union, which contains 'a rebuttable presumption of the existence of an employment contract with a minimum amount of paid hours based on the average hours worked during a given period' (Art 11(b)). ${ }^{40}$ This legal presumption applies to on-demand or similar employment contracts - that is, where it is already established that an employment contract exists but the number of working hours has not been fixed - and is only one of three options, the others being limitations on the use and duration of such contracts or equivalent measures that ensure effective prevention of abusive practices, EU Member States have to adopt. Art 11(4) of Directive (EU) 2019/1152, which applies to on-demand or similar employment contracts, and determines that Member States have the option to introduce 'a rebuttable presumption of the existence of an employment contract with a minimum amount of paid hours based on the average hours worked during a given period' in order to prevent abusive practices. An alternative to the legal presumption that has been suggested by the Commission is shifting the burden of proof or lowering the standard of proof required of people engaged in platform work or their representatives in legal proceedings. That way, platform workers would not automatically be considered to be in an employment relationship, but would need to set out a few facts from which it could be presumed that an employment relationship exists (i.e., prima facie evidence). The onus would then be on the online platform could then prove that the person is actually self-employed. One important limitation of this alternative mentioned by the European Commission is that platform workers would still need to take a case in court, with the associated costs and risks that entails. ${ }^{41}$ Two other options discussed by the European Commission are the use of an administrative procedure

36. This was particularly mentioned in the context of non-standard employment, see ILO, Non-standard Employment Around the World: Understanding Challenges, Shaping Prospects (Geneva, International Labour Organization, 2016) 330 .

37. A brief reference to Art 153 TFEU can be found in C(2021) 1127 final, 29 and C(2021) 4230 final, 26.

38. See also Garben, “'Old” Rules and Protections for the "New" World of Work'.

39. C(2021) 1127 final, 27.

40. A similar presumption can be found in Dutch labour law, namely, Art 7:610b Civil Code. Art 6(3) Directive 2009/52/EC providing for minimum standards on sanctions and measures against employers of illegally staying third-country nationals also contains a presumption on back payments to be made by employers, according to which 'an employment relationship of at least three months duration will be presumed, unless, among others, the employer or the employee can prove otherwise'.

41. C(2021) 4230 final, 22. 
to examine the employment status of such workers, sparing them the costs and risks associated with legal proceedings; and an out-of-court - and not directly enforceable - certification of work-related contracts carried out by labour authorities or the like. ${ }^{42}$ However, even in both alternatives, court proceedings might still be necessary in the end.

Not only is it likely that the same legal basis would be used for a legal presumption in relation to platform work, but based on the Transparent and Predictable Working Conditions Directive, it is also quite likely that the European Commission will offer EU Member States a choice of measures to introduce, among which will be a rebuttable legal presumption. ${ }^{43}$ As Sacha Garben rightly pointed out, 'labour status is sensitive with the member states', so leaving EU Member States some choice as to the specific measure to be adopted could possibly address the fear that the EU's legal competence would cross a certain line while allowing for the fact that not all Member States' labour law systems have rebuttable legal presumptions on the existence of an employment relationship. One danger of granting EU Member States some discretion in introducing a rebuttable legal presumption or an alternative instrument is that platform workers would not benefit from a presumption in all EU Member States. Another issue to take into account is that a presumption would only apply to work performed within the European Union, as only EU Member States would be bound by it.

\subsection{Different rebuttable legal presumptions}

A rebuttable legal presumption may take different forms. First, a presumption may determine that a worker engaged in platform work - which the future EU initiative to improve the working conditions of people working in the platform economy would need to define - is presumed to perform such work pursuant to a contract of employment. Second, it may determine that a worker who performs platform work for remuneration for a certain period of time, for instance, three consecutive months, weekly or not less than twenty hours per month, is presumed to perform such work pursuant to a contract of employment. ${ }^{44}$ Third, it could be determined that all 'platform workers are entitled to all the rights and protections applicable to workers under EU law, unless their relationship to the platform clearly does not feature the essential characteristics of an employment relationship and they are to be regarded as self-employed in light of, in particular, their full autonomy in terms of the pricing, organisation and execution of the work in question. ${ }^{45}$

Either option should be complemented by stating that the legal presumption can be rebutted by the online platform if it can prove that parties do not have an employment relationship, which might be the case where the parties clearly did not have the intention of concluding an employment contract - something the platform would most likely argue. In addition, and more importantly, however, the platform should be required to prove that the parties have not actually implemented or put into practice the contract in such a way that would imply that it is a contract of employment. ${ }^{46}$ Adding

42. ibid.

43. A similar strategy has been followed with the subcontracting liability laid down in Art 12 Directive (EU) 2014/67 on the enforcement of Directive 96/71/EC on the posting of workers.

44. The second option is derived from Dutch law, Art 7:610a Civil Code.

45. Garben, “Old" Rules and Protections for the "New" World of Work'. Sacha Garben adds a similar provision for the application of national labour law.

46. This is derived from Guus Heerma van Voss, 'The Netherlands' in Bernd Waas and Guus Heerma van Voss (eds), Restatement of Labour Law in Europe: The Concept of Employee, vol I (Oxford, Hart, 2017). 
this requirement might be difficult to prove for some online platforms where they exercise algorithmic control to determine the level of income a worker can and will generate and the frequency of task offers, which often depend on the level of ratings. Ultimately, the promised freedom for platform workers becomes largely illusory and is rather a freedom to the benefit of the online platform. ${ }^{47}$ Furthermore, the legal presumption could be complemented, as ETUC suggests, 'by a reversal of the burden of the proof for platform companies seeking to establish that they are not the worker's employer'. ${ }^{48}$ Here, ETUC seems to rely on research conducted by Nicola Countouris and Valerio De Stefano on 'New Trade Union Strategies for New Forms of Employment', where the authors suggest 'that it may be useful to introduce a legal presumption of employer status upon the entity, or entities "substantially determining" the terms of engagement and employment of the worker', which could help in identifying 'the types of obligations and liabilities (individual and shared) arising in each context' ${ }^{49}$ This would assist in addressing the question of 'who is or who are the employer(s)?'. ${ }^{50}$ Ultimately, however, a rebuttable legal presumption will not entail a material change to the EU definition of 'worker' or the national definitions of the employment contract or relationship, but will involve an amendment of an evidentiary nature. Yet, a presumption seems to be a hybrid instrument being, at the same time, closely related to notions of the employment contract or relationship and notions of employee while also carrying features of a procedural measure that helps platform workers to access the rights and entitlements that derive from EU and national labour law.

\subsection{The impact of introducing an EU legal presumption}

If the EU was to introduce a rebuttable legal presumption on the existence of an employment relationship for platform workers through a legislative initiative, the question would then arise as to the impact such a presumption would have within EU law, first, with regard to the notion of 'worker' and, second, with regard to cross-border situations. This question is derived from the CJEU's case law on the notion of 'worker'. Initially developed in the context of the free movement of workers through the infamous Lawrie-Blum ruling, ${ }^{51}$ throughout its case law, the CJEU has broadened the scope of application to Art 157 TFEU, ${ }^{52}$ the Working Time Directive 2003/88/EC ${ }^{53}$ and Directive $92 / 85 /$ EEC on the introduction of measures to encourage improvements in the safety and health at work of pregnant workers and workers who have recently given birth or are breastfeeding. ${ }^{54}$ Thus,

47. See, on algorithmic management practices: Alex J Wood, Algorithmic Management: Consequences for Work Organisation and Working Conditions (European Commission, 2021)

48. Resolution adopted at the virtual Executive Committee meeting on 22-23 March 2021, 'ETUC reply to the First phase consultation of social partners under Article $154 \mathrm{TFEU}$ on possible action addressing the challenges related to working conditions in platform work' <www.etuc.org/sites/default/files/document/file/2021-04/ETUC\%20reply $\% 20$ to $\% 20$ the $\%$ 20First $\% 20$ phase $\% 20$ consultation\%20of\%20social\%20partners\%20\%20platform\%20work.pdf $>$ accessed 19 July 2021.

49. Countouris and De Stefano, 'New Trade Union Strategies' 17.

50. See, on the concept of the employer more generally: Jeremias Prassl, The Concept of the Employer (Oxford, Oxford University Press, 2015).

51. Case 66/85 Lawrie-Blum ECLI:EU:C:1986:284.

52. Case C-256/01 Allonby ECLI:EU:C:2004:18.

53. Case C-427/09 Union syndicale Solidaires Isère ECLI:EU:C:2010:612.

54. Case C-232/09 Danosa ECLI:EU:C:2010:674. See, more extensively, on the CJEU's role in defining who is a worker within the meaning of EU law: Nicola Kountouris, 'The Concept of "Worker" in European Labour Law: Fragmentation, Autonomy and Scope' (2017) 46 Industrial Law Journal 192. 
although the CJEU regularly uses the Lawrie-Blum formula, EU law is not based on a uniform concept of 'employee' that is applicable throughout EU law. Instead, it has been developed for each legal Act separately and must be determined accordingly for each legal Act on which the CJEU has not yet ruled and where a legal Act does not explicitly state that national definitions of 'worker' provide the scope of applicability.

If the definition of 'worker' depends on each individual legal Act and may sometimes, explicitly or implicitly, refer to a national definition or an EU definition, for a platform worker to actually benefit from being classified as a worker unless the opposite can be proven by the employing entity, it would be wise to follow the suggestion made by Sacha Garben, who drafted tentative provisions determining that 'online platform workers are entitled to all the rights and protections applicable to workers under EU law', and that 'Member States shall ensure online platform workers all the rights and protections under the relevant national law applicable to persons with an employment contract'. ${ }^{55}$ This, she adds, might even include the applicability of rights and entitlements for genuinely self-employed platform workers. While it would be possible to argue that Art 153 TFEU could also be used as a legal basis in relation to genuinely self-employed platform workers, uncertainty might be addressed by also using Art 53 TFEU or Art 352 TFEU. ${ }^{56}$

Against this background, the interests of platform workers are probably best served if the EU initiative to improve the working conditions of people working in the platform economy contains a presumption on the existence of an employment relationship which clarifies that they are entitled to all workers' rights granted based on EU and/or national law. This would 'help platforms and people working through platforms to correctly establish the classification of employment status in line with national definitions, taking into account the imbalance of power between the platforms and the people working through them. ${ }^{57}$ Yet, depending on how the rebuttable legal presumption is phrased, it may apply to online platforms as well. By invoking the legal presumption, employing entities could trigger a shift in the burden to prove the opposite to platform workers. Nevertheless, the main aim of a rebuttable legal presumption would be to protect platform workers.

With regard to cross-border situations, introducing a legal presumption, even if rebuttable, might be considered an obstacle to the free movement of services, as laid down in Art 56 TFEU. In a case concerning a French law provision on the presumption of salaried status for performing artists, the CJEU ruled that even though a presumption constitutes a procedural measure, the presumption in that case did not serve to guarantee rights derived from EU law but, on the contrary, placed a restriction on such rights, referring to Art 56 TFEU, in particular. ${ }^{58}$ Arguably, this presumption would discourage artists from providing their services in France and discourage organisers of events from engaging such artists. ${ }^{59}$ The French Government justified the presumption, first, by ensuring that self-employed performing artists, similar to employed persons, enjoyed social protection, including the right to paid leave, which, according to the CJEU, is difficult to reconcile with the concept of self-employment. ${ }^{60}$ Second, the French Government sought to combat concealed employment, an aim that is relevant in relation to the (mis)classification of platform workers. However, the fact that performing artists are normally engaged on an intermittent basis and for

55. Garben, “"Old” Rules and Protections for the "New” World of Work'.

56. ibid.

57. C(2021) 4230 final, 21-22.

58. Case C-255/04 Commission/France ECLI:EU:C:2006:401, para 40.

59. ibid, para 38 .

60. ibid, para $47-51$. 
short periods by different show organisers does not mean that a general assumption of concealed employment is well-founded. ${ }^{61}$

With a regard to platform work, and protecting platform workers, in particular, however, it can be argued that the intention of a rebuttable legal presumption regulated at the EU level would be to offer these workers a means to establish their employment status and therefore entitle them to rights derived from EU law. Moreover, given that the main issue with platform work is the false classification of platform workers as self-employed, as is also recognised by the EU institutions, combating misclassification would be an objective reason. It is, therefore, very likely that the Commission/ France case will have no effect on the introduction of a legal presumption regulated within EU law with the aim of addressing the misclassification of platform workers and entitling them to rights that derive from EU law, and such a presumption will not be subject to the CJEU's restrictive interpretation adopted in the Commission/France case. That is not to say that a legal presumption does not have the potential to make cross-border movements less attractive. However, the question will be what the presumption actually sets out to protect. It might be different when there is a political intention at the EU level to address the false classification of platform workers, compared to when there is only a national approach, thereby possibly constituting a justifiable restriction to the freedom to provide services. Certainly, online platforms are likely to argue that their whole business model is based on the idea of flexibility and that, following this, individuals providing services through platforms are classified as self-employed workers. Yet, where their actual situation resembles more that of an employee than of a self-employed person, this line of reasoning is not likely to hold. Also, I would argue that employment relationships offer a wide range of possibilities to allow for flexibility. However, this does not include a form of flexibility that seeks to reduce hourly labour costs to increase profit.

\section{Conclusion}

Having set out the benefits and limitations of introducing a rebuttable legal presumption on the existence of an employment relationship for platform workers within EU law, it is quite likely that the EU initiative to improve the working conditions of people working in the platform economy will contain a presumption with one or more alternatives. This assertion is based on previous strategies pursued by the European Commission in Directive (EU) 2014/67 on the enforcement of posted workers' rights in relation to subcontracting liability, and in Directive (EU) 2019/ 1152 on transparent and predictable working conditions in relation to establishing the amount of working hours where they were not fixed according to an employment contract. Moreover, not all EU Member States have rebuttable legal presumptions on the existence of the employment relationship, which makes it very likely that alternative instruments will be availale. As a rebuttable legal presumption is an evidentiary instrument, according to which work relations that meet all relevant criteria will be classified as employment relationships, it can be seen as being related to provisions dealing with the notion of the employment contract or the employee. Yet, at the same time, it does offer platform workers a tool that assists them when it comes to establishing their rights under EU and national labour law. The second-phase consultation was launched by the Commission only on 15 June 2021, and social partners had until 15 September 2021 to respond to the questions. Based on the results, and depending on the political will of the stakeholders involved, it remains

61. ibid, para 52 . 
to be seen whether we will see a proposal for a Directive on the protection of platform workers containing a rebuttable legal presumption, including alternatives.

\section{Declaration of conflicting interests}

The author(s) declared no potential conflicts of interest with respect to the research, authorship, and/or publication of this article. 